\title{
Hydroponic Vegetable Production in Florida ${ }^{1}$
}

\author{
Richard Tyson, Robert Hochmuth and Daniel J. Cantliffe ${ }^{2}$
}

\section{History of the Industry in Florida}

The greenhouse hydroponic vegetable industry in Florida has changed significantly over the past 15 years (Tyson et al., 2004; Tyson et al., 2001) due to shifts in market demand, adverse weather, and research-based innovations in new crops, as well as improvements in production cost and efficiency (Resh, 2004, Shaw and Cantliffe, 2002; Shaw et al., 2000; Stapleton and Hochmuth, 2001; Sweat et al., 2003).

These changes in crops produced (Table 1), hydroponic systems employed (Table 2) and greenhouse designs (Table 3) demonstrate the ability of growers to adapt. However, these dynamics also reflect the general instability of this industry as it competes with less expensive, field-grown and imported vegetables. Hurricanes and tropical storms in Florida also contribute to uncertainty in this industry since large greenhouse ranges located near coastal areas can be destroyed overnight, as occurred in Collier County in 2004.

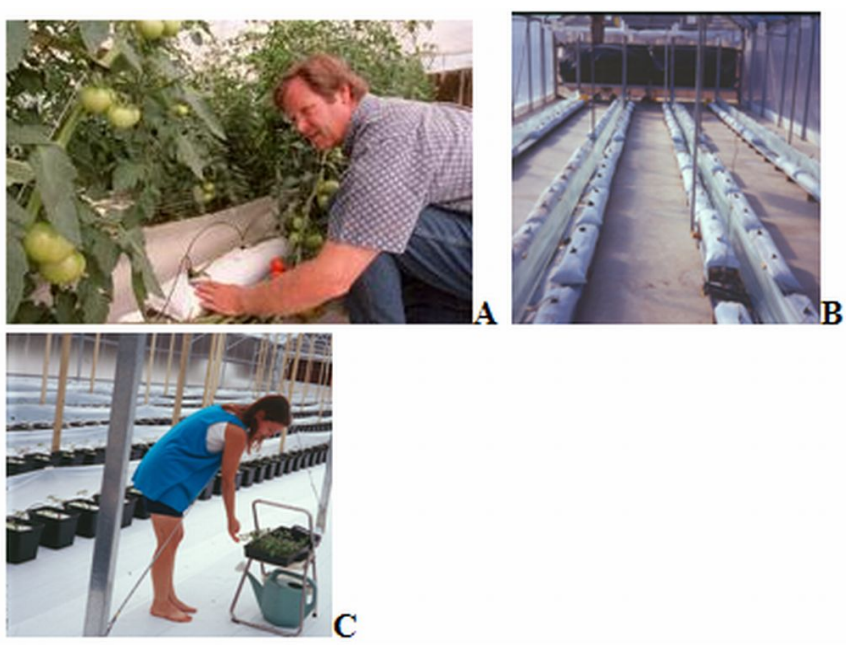

Figure 1. Photos A and B, taken in 1995 in a greenhouse at UF's North Florida Research and Education Center in Live Oak, FL, show a perlite lay-flat-bag system. Photo C pictures a Dutch-bucket system in a greenhouse in Sanford, FL, in 2004.

\section{Marketing Considerations}

Most successful hydroponic growers in Florida do their own direct marketing, thus circumventing the wholesale market channels traditionally used by producers of field-grown vegetables. Through traditional wholesale channels, farmers and ranchers typically receive only about 20 percent of the retail

1. This document is HS405, one of a series of the Horticultural Sciences Department, Florida Cooperative Extension Service, Institute of Food and Agricultural Sciences, University of Florida. Original publication date, November 2009. Visit the EDIS Web site at http://edis.ifas.ufl.edu.

2. Richard Tyson, director, Orange County Extension Office, Orlando, FL; Robert Hochmuth, multicounty extension agent, North Florida Research and Education Center--Live Oak, FL; and Daniel J. Cantliffe, distinguished professor emeritus and chair, Horticultural Sciences Department, Institute of Food and Agricultural Sciences, University of Florida, Gainesville, FL.

The Institute of Food and Agricultural Sciences (IFAS) is an Equal Opportunity Institution authorized to provide research, educational information and other services only to individuals and institutions that function with non-discrimination with respect to race, creed, color, religion, age, disability, sex, sexual orientation, marital status, national origin, political opinions or affiliations. U.S. Department of Agriculture, Cooperative Extension Service, University of Florida, IFAS, Florida A. \& M. University Cooperative Extension Program, and Boards of County Commissioners Cooperating. Interim Dean Millie Ferrer. 
value of their crop (Anonymous, 2009). Off-farm costs -- including marketing, processing, wholesaling, distribution and retailing -- account for 80 cents of every retail food dollar spent in the United States. However, producers' chances for success improve when they place their crops as close as possible to retail markets -- restaurants, cafeterias, hotels, cruise ships, farmers markets, on-farm-sales, etc.

Because of the greater cost per pound of producing hydroponic vegetables -- as compared to traditional, field-grown vegetables -- hydroponic growers, to be successful, need to receive 50 - 100 percent of the retail value for their crops. Actual retail values can be determined easily by checking several local retail grocery stores for vegetable prices. However, to move large loads, high-volume producers ( $>0.5$ acre) will still need to cultivate some wholesale markets (with lower prices per pound shipped).

\section{Hydroponic Growing Systems}

Based on the latest published data (Table 1), hydroponic-crop rankings in Florida - ordered from most grown to least grown - were the following: herbs, peppers, cucumbers, tomatoes, lettuce, mixed vegetable/herb, and strawberries.

These crops were produced in the following production/media type systems (Table 2): perlite (Dutch bucket, lay flat bag); various media-filled nursery pots or upright bags; raised beds or sand floor; nutrient film (flow) technique (NFT); floating raft systems; vertical systems; or rockwool. Greenhouse design (Table 3) was natural ventilation or pad and fan with mostly double polyethylene covers in multiple-bay greenhouses.

\section{Perlite}

Perlite is a generic term for naturally occurring volcanic glass or rock, which is heated and, in response, expands from four to 20 times its original volume. The result is a white, angular, pearl-like pebble that is light weight and adaptable for numerous applications, including as horticultural media.
Perlite systems for growing vegetables hydroponically are varied in design. One system uses drip-irrigated, perlite-filled, lay-flat plastic bags. (See Figure 1). These cigar-shaped bags are placed in two rows, running the length of the greenhouse with access aisles in between. Slits are made at the bottom or slightly up one side of each bag for drainage to a central collection trough running between the rows. Effluent from the bags collects in the trough and may remain there or run by gravity to a collection tank.

Another common perlite system uses Dutch buckets. This system consists of plastic, two-gallon buckets containing perlite and with a 2-two inch reservoir at the bottom. Drip irrigation supplies water and nutrients, which overflow the reservoir and are collected to drain or recycled through a PVC pipe.

Perlite is also used in a variety of other cropping systems, including the bench-bed system (example: perlite-filled, aluminum roofing panels) and vertical systems (described below). When used in these systems, perlite is often mixed with coconut coir, peat, or other organic components to increase water and nutrient holding capacity of the media.

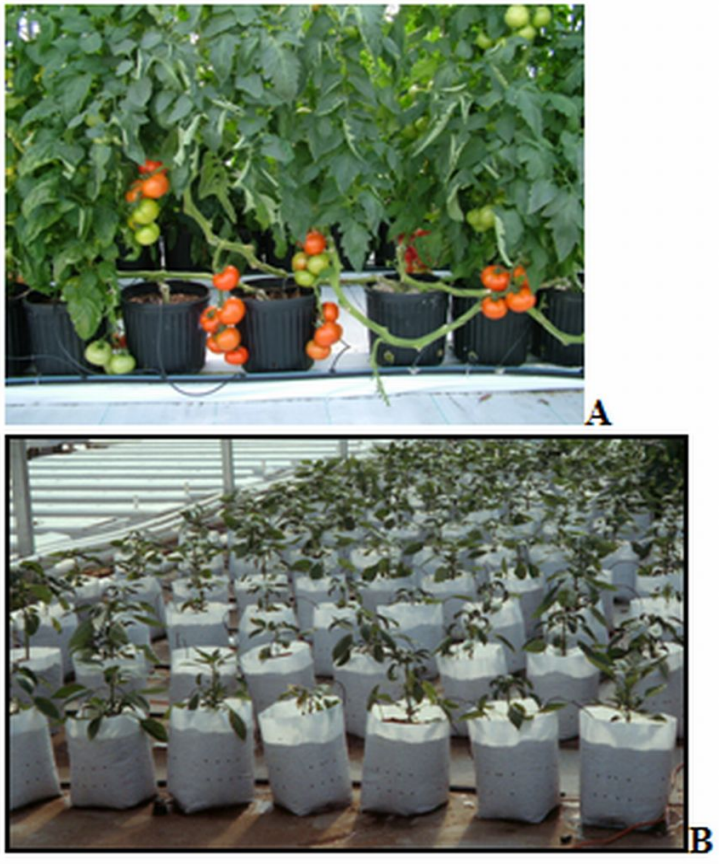

Figure 2. Tomatoes growing in media-filled, plastic nursery pots (A) and in upright bags (B) in a greenhouse in Wellborn, FL, in 2001. 


\section{Media Filled Plastic Nursery Pots or Upright Bags}

Media filled plastic nursery pots (Figure 2A) or upright bags (Figure 2B) can be spaced in two rows similar to lay-flat bag and rockwool culture. This system is similar to those used by ornamental growers in Florida, who grow drip-irrigated foliage or landscape plants in containers.

Composted pine bark is a common media with this system because of the availability of this media from the forest-pulp industry in Florida. Other media commonly used in this system include one or more combinations of peat, perlite and vermiculite.

Drip irrigation supplies a nutrient solution to the containers. The solution is usually not re-circulated, but timed to pulse-flow through the containers.

\section{Soil Mix Raised Beds}

The soil mix raised beds hydroponic system consists of a potting-mixture combination of peat, perlite, vermiculite, composted product or similar substrate, mixed together with or without fertilizer (Figure 3). Drip irrigation supplies water and nutrients to crops grown similar to outdoors, in rows, but under the protected greenhouse structure. This category includes crops reported as "native soil floor."

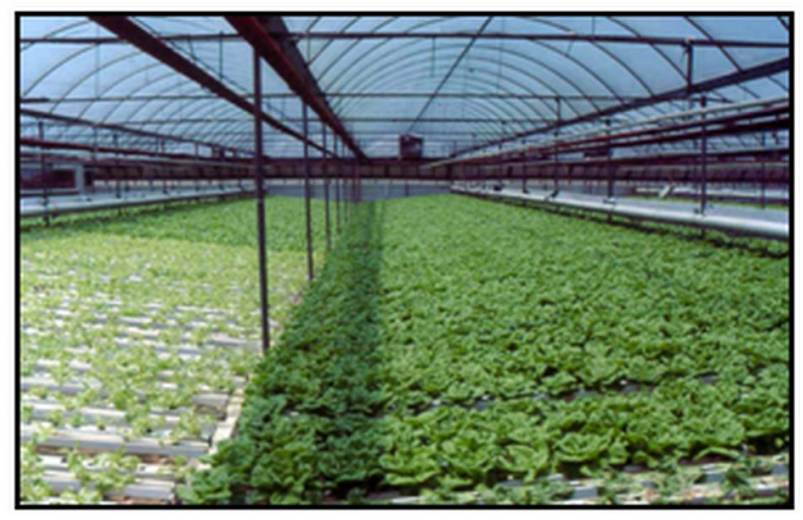

Figure 4. Bibb lettuce growing in a hydroponic system that uses nutrient film (flow) technique in a greenhouse in Live Oak, FL, 1995.

\section{Nutrient Film Technique}

The nutrient film technique (NFT) is a water-culture technique that uses no media. Plants are grown with roots contained in a plastic film, trough or PVC pipe. Nutrient-laden water is re-circulated through the system, bathing the roots. This system is still popular for short-term crops, such as lettuce and basil, where the plants are sold with the roots intact. This system was also popular in the 1990s for several small-farm tomato operations.

Because of the risk of root pathogens being spread throughout the greenhouse once an infection starts, most tomato growers are no longer using recirculating systems unless the system includes some means of sterilizing the water. Instead, many tomato and pepper growers now use some variation of a media nutrient flow-through system, such as the lay-flat bag, Dutch bucket or rockwool systems, which do not recirculate the nutrients. In these systems, root infections remain localized.

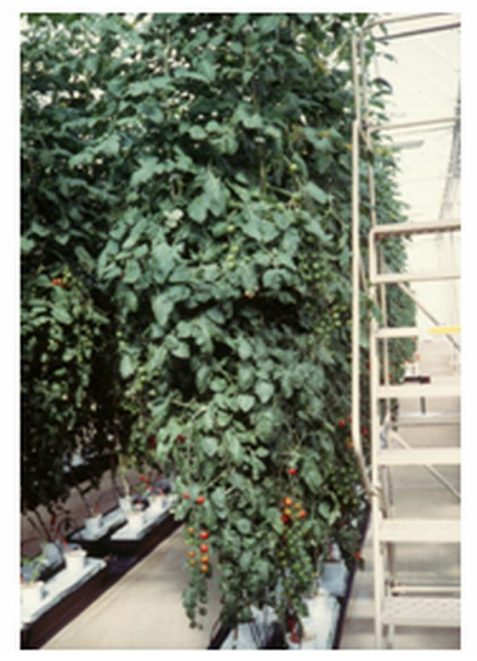

Figure 5. Rockwool hydroponic culture in a greenhouse in Lake Buena Vista, FL, 1998.

\section{Rockwool Culture}

Rockwool culture (Figure 5) was the most common hydroponic production system in Florida during the 1990s. Rockwool is an inert, fibrous material produced from a heated mixture of volcanic rock, limestone, and coke. Rockwool is extruded as fine threads and pressed into loosely woven sheets. Use of rockwool declined in favor of perlite primarily 
because of the greater cost of materials and the difficulty of disposal; in both of these areas, perlite has an advantage.

Rockwool production techniques are similar to perlite lay-flat bags, with drip irrigation through the rockwool slabs, two rows draining to a central collection trough, and gravity feeding of the effluent to a collection tank. The solution can be sterilized and re-circulated or flow through and used for another purpose, such as providing water and nutrients for an adjacent float system.
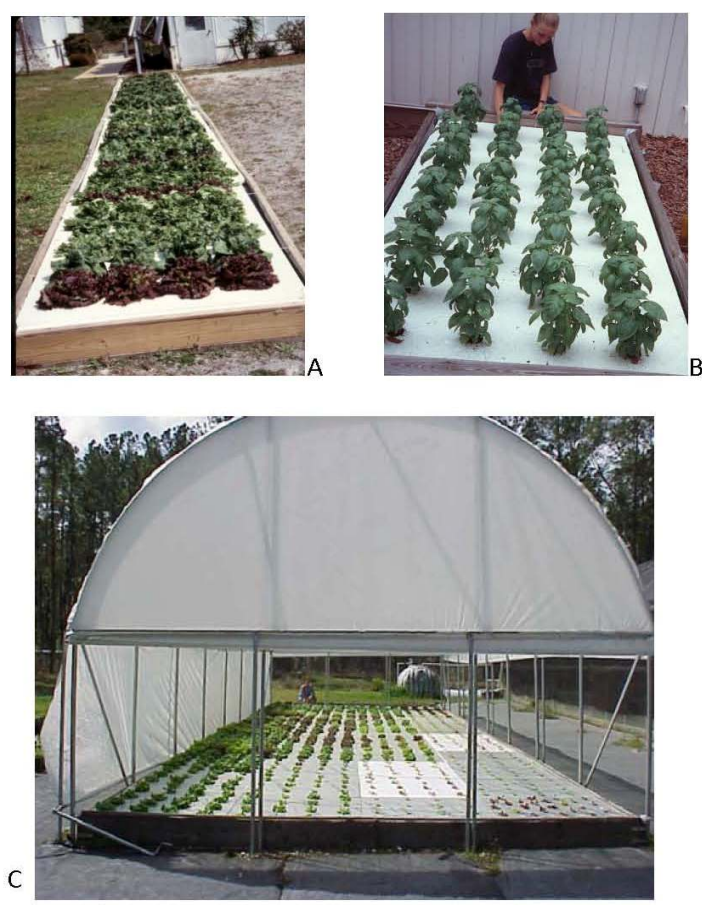

Figure 6. Floating raft hydroponic systems in Sanford, FL, 2007.

\section{Floating Raft Systems}

Floating raft hydroponic systems and vertical systems (see below) are popular, new hydroponic systems that were not even reported in 1991. The floating systems utilize the floating-raft or mat system, in which Styrofoam rafts with holes drilled in them are floated on nutrient-rich water (Sweat et al., 2003). This system works well with short-season, shallow-rooted crops -- such as lettuce, basil, and watercress, which grow well under high-moisture conditions in the root zone. High-tech versions of this system can be expensive to build and operate, but low-tech versions have been tested and are in use on small farms in Florida (Figure 6).

\section{Vertical Systems}

Vertical hydroponic systems produce crops in upright or vertical rows, a method that can significantly increase plant populations. The most common vertical systems include stacked pots (Figure 7), stacked and sloped PVC pipes, and hanging vertical bags. The potential for increased yield in vertical systems is sometimes offset by the non-uniformity of product due to competition for light and space.

The vertical systems are popular for producing strawberries, leafy greens, edible flowers and fresh-cut herbs. More recently, vertical-production techniques have also been developed for tomato.
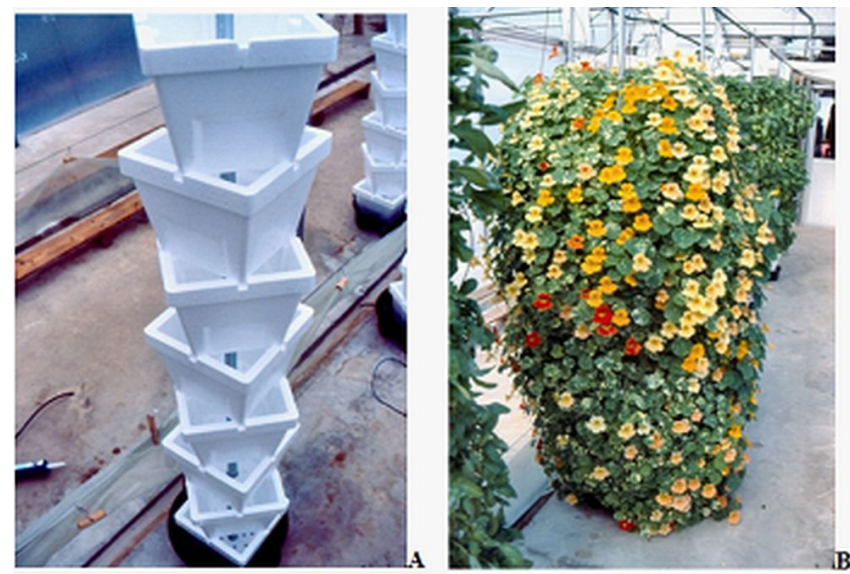

Figure 7. Verti-Gro ${ }^{\circledR}$ stacked pots (A) planted with nasturtium (B) in a vertical hydroponic system in Live Oak, FL, 2001.

Web sites of some currently available vertical systems are identified below.

Hydro-Stacker -- http://www.hydrostacker.com/

Green Tower --

http://www.greenworldpath.com/hydroponic-

containers-accessories/green-tower-gro/prod_92.html

Tower Garden --

http://www.futuregrowing.com/Towergarden.htm

Verti-Gro -- http://vertigro.com/ 


\section{Media-filled Trough}

The media-filled trough is a hydroponic system gaining in popularity due to the potential for adding media that can be certified organic (Figure 8). These growing systems use different liner materials to produce a trough that will hold a media selected by the grower. A drip system runs the length of the trough, uniformly providing water.

In the case of organically certified systems, the nutrients are included with the media. In solely hydroponic systems, soluble synthetic fertilizers are injected into the irrigation line.
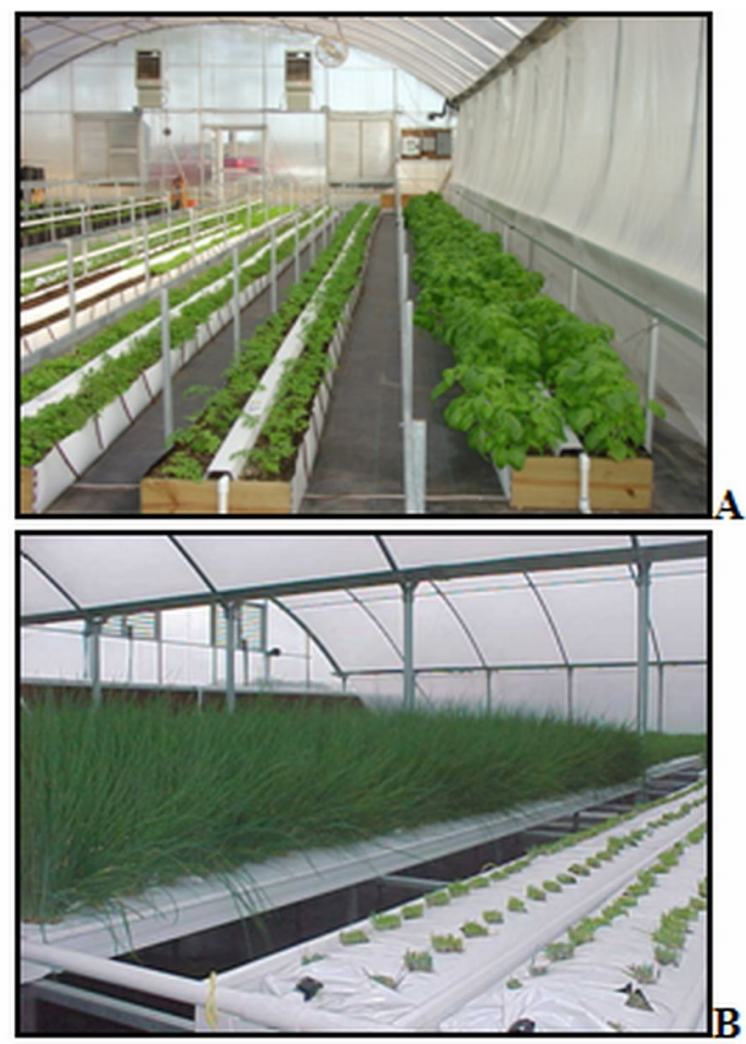

Figure 8. These photos -- taken in a greenhouse in McAlpin, FL, in 2006 -- picture (A) a crop of mixed herbs for fresh-cut, grown in an open trough filled with a peat-based mix and $(B)$ a chives crop in perlite bags in a trough.

\section{Fertilizer Stock Tanks}

In most hydroponic production systems, at least two fertilizer stock tanks are needed. One tank contains calcium nitrate, and the other contains a "premix" of a complete package of nutrients without calcium. Large growers often choose to mix their own fertilizer batches with individual ingredients to reduce cost.

Once concentrated nutrients are mixed in the tanks, the mix is injected directly into the water line that goes to the drip system. Complete directions and recipes for the premix and individual ingredient method are available for Florida conditions (Hochmuth and Hochmuth, 2008). (See Nutrient Solution Formulation for Hydroponic -- Perlite, Rockwool, NFT -- Tomatoes in Florida, http://edis.ifas.ufl.edu/CV216.)

Small hydroponic units, which dont require large volumes of solution, can mix all the fertilizer directly into a mini-bulk tank and use a sump pump to route the solution to the plants.

\section{Seasonal Limitations to Greenhouse Hydroponic Production in Florida}

While this publication generally focuses on information for greenhouse hydroponic production systems and crops, growing vegetables in greenhouses during the summer months in Florida can be problematic due to heat, humidity and pest buildup that can occur. Additionally, prices for vegetables are usually low during the summertime.

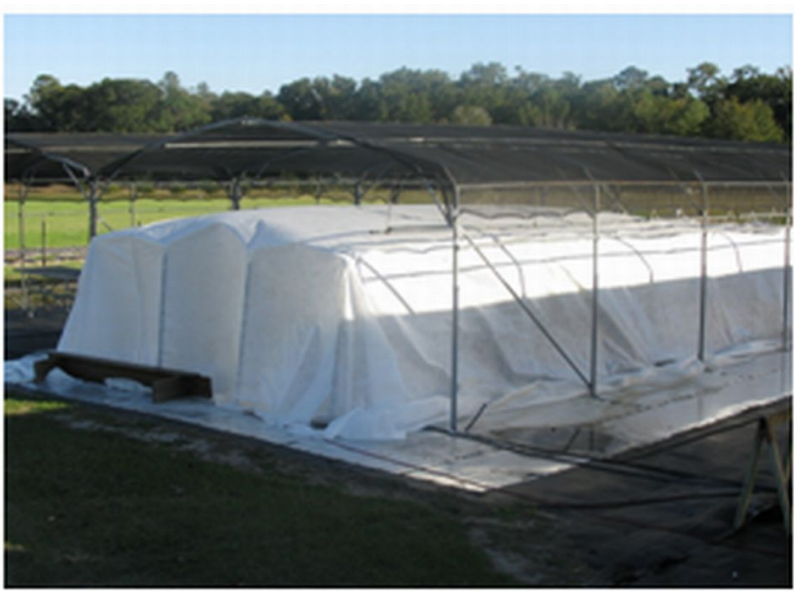

Figure 9. A tomato crop under a polypropylene frost cover outdoors in December, 2008, in Live Oak, FL.

However, Florida's mild climate also provides opportunities for hydroponic growing systems to be used successfully outside. The following two illustrations - figures 9 and 10 -- picture outdoor hydroponic systems in Live Oak, FL. 
Outdoor hydroponic systems typically are used with some provision for frost protection with row-cover materials. (See Figure 9.) In addition, there is an increasing interest in extending the hydroponic growing season into the summer by using open shade structures (Hochmuth et al., 2007) to supply vegetables for local markets. (See Figure 10.)

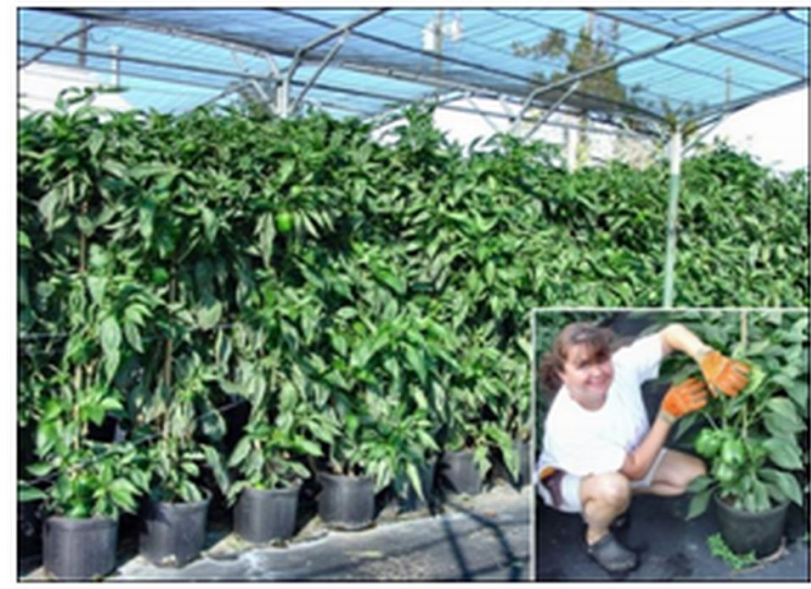

Figure 10. A hydroponic system outdoors, under shade, in Live Oak, FL, October, 2007.

\section{Economic Considerations}

Regardless of which crop, which cropping system or which greenhouse one chooses, the cost of producing vegetables in a greenhouse is -- for most vegetables -- about double the cost of producing the same vegetables in the field.

Additionally, since the North American Free Trade Agreement was implemented in 1994, imported produce supplies are increasing in the United States and are generally depressing vegetable markets in this country. As a result, Floridas total acreage of field-grown vegetables has dropped 25 percent over the past 15 years.

Growing is only half the battle producers face. To succeed, growers must find consistent markets that pay the growers a premium price for their produce. Marketing strategies that target high-end consumers -- willing to pay more for locally grown, fresh, greenhouse vegetables -- are important to maximize returns on greenhouse-grown vegetables.

\section{More Information}

For further information (including a series of brief videos ) on hydroponic growing systems, crops, and techniques, visit the hydroponic section of the Virtual Field Day Web site -- http://vfd.ifas.ufl.edu -or the hydroponic page of the small farms Web site -http://smallfarms.ifas.ufl.edu/crops/hydroponics/ index.html.

\section{References}

Anonymous. 2009. National Farmers Union www.nfu.org . Retrieved from http://nfu.org/issues/agriculture-programs/resources/ farmers-share on 2/9/09.

Hochmuth, G.J. and R.C. Hochmuth. 2008. Nutrient solution formulation for hydroponic (perlite, rockwool, NFT) tomatoes in Florida. EDIS Publication HS-796:13pgs.

http://edis.ifas.ufl.edu/CV216. Horticultural Sciences Department, University of Florida, Gainesville, FL.

Hochmuth, R.C., D.D. Treadwell, E.H. Simone, L.D. Landrum, W.L. Laughlin and L.L. Davis. 2007. Growing bell peppers in soilless culture under open shade structures. EDIS Publication HS-1113:5pgs. http://edis.ifas.ufl.edu/pdffiles/HS/HS36800.pdf. Horticultural Sciences Department, University of Florida, Gainesville, FL.

Resh, H.M. 2004. Hydroponic Food Production, 6th ed. New Concept Press Publishing Co., Mahwah, NJ.

Shaw, N.L. and D.J. Cantliffe. 2002. Brightly colored pepper cultivars for greenhouse production in Florida. Proc. Fla. State Hort. Soc. 115:236-241.

Shaw N.L., D.J. Cantliffe, J.C. Rodriguez, S. Taylor and D.M. Spenser. 2000. Beit alpha cucumber - and exciting new greenhouse crop. Proc. Fla. State Hort. Soc. 113:247-253.

Stapleton, S.C. and R.C. Hochmuth. 2001. Greenhouse production of several fresh-cut herbs in vertical hydroponic systems in north central Florida. Proc. Fla. State Hort. Soc. 114:332-334. 
Sweat, M., R. Tyson and R. Hochmuth. 2003.

Building a floating hydroponic garden. EDIS

Publication HS-943:4pgs.

http://edis.ifas.ufl.edu/HS184. Horticultural Sciences

Department, University of Florida, Gainesville, FL.

Tyson, R., R. Hochmuth, E. Lamb, E. McAvoy, T. Olczyk and M. Lamberts. 2004. Greenhouse vegetables in Floridas mild winter climate - 2004 update. Acta Horticulturae 659:37-40.

Tyson, R.V., R. C. Hochmuth, E.M. Lamb, G.J. Hochmuth, M.S. Sweat. 2001. A decade of change in Floridas greenhouse vegetable industry. Proc.

Fla. State Hort. Soc. 114:280-283. 
Hydroponic Vegetable Production in Florida

Table 1. Greenhouse Vegetable Crops Produced in Florida, 1991-2004.

\begin{tabular}{|r|r|r|r|r|r|r|r|}
\hline \hline \multicolumn{7}{|c|}{ Total Square Meters per Crop } \\
\hline Year & \multicolumn{1}{|c|}{ Tomato } & \multicolumn{1}{c|}{ Pepper } & Cucumber & Lettuce & Herbs & \multicolumn{1}{c|}{ Strawberry } & \multicolumn{1}{c|}{ Mixed } \\
\hline $\mathbf{1 9 9 1}$ & 85,349 & 3,423 & 170,698 & 5,334 & 525 & NR & 1,403 \\
\hline $\mathbf{1 9 9 6}$ & 19,834 & 23,234 & 159,101 & 7,571 & 18,601 & 1,426 & 3,159 \\
\hline $\mathbf{2 0 0 1}$ & 74,156 & 155,013 & 48,352 & 29,170 & 68,305 & 4,022 & 6,770 \\
\hline $\mathbf{2 0 0 4}$ & 39,416 & 86,126 & 56,755 & 24,771 & 75,710 & 5,113 & 10,197 \\
\hline \hline
\end{tabular}

Table 2. Greenhouse Vegetable Crop Production Systems in Florida, 1991-2004.

\begin{tabular}{|c|r|r|r|r|r|r|r|r|r|}
\hline \hline \multicolumn{10}{|c|}{ Total Square Meters per System } \\
\hline Year & Rockwool & NFT & Trough & Bed/floor & Pot/bag & Perlite & Float & Vertical & Other \\
\hline $\mathbf{1 9 9 1}$ & 173,365 & 66,679 & 10,669 & 4,283 & 6,782 & NR $^{2}$ & NR & NR & 4,939 \\
\hline $\mathbf{1 9 9 6}$ & 743 & 15,979 & 232 & 2,880 & 232 & 206,762 & 3,252 & NR & 2,835 \\
\hline $\mathbf{2 0 0 1}$ & 11,624 & 13,993 & 1,858 & 29,861 & 9,780 & 292,993 & 9,151 & 5,097 & 11,433 \\
\hline $\mathbf{2 0 0 4}$ & 1,672 & 19,076 & 743 & 28,699 & 60,771 & 167,694 & 4,716 & 3,559 & 11,158 \\
\hline \hline
\end{tabular}

Table 3. Greenhouse Design Used in Vegetable Crop Production in Florida, 1991-2004.

\begin{tabular}{|c|r|r|r|r|r|c|}
\hline \hline \multicolumn{7}{|c|}{ Total Square Meters per Design } \\
\hline Year & Sing./D. Bay & Multi-bay & Double poly & Single poly & Pad \& fan & Natural vent \\
\hline $\mathbf{1 9 9 1}$ & 18,670 & 248,046 & NR $^{2}$ & NR & NR & NR \\
\hline $\mathbf{1 9 9 6}$ & 9,359 & 223,557 & 197,572 & 35,344 & NR & NR \\
\hline $\mathbf{2 0 0 1}$ & 20,018 & 365,770 & 317,066 & 68,722 & 243,987 & 141,801 \\
\hline $\mathbf{2 0 0 4}$ & 22,489 & 267,628 & 199,969 & 78,846 & 125,515 & 172,147 \\
\hline \hline
\end{tabular}

